\begin{tabular}{|l|l|l||}
\hline \multicolumn{2}{|c|}{ PublisherInfo } \\
\hline \hline PublisherName & $:$ & BioMed Central \\
\hline \hline PublisherLocation & $:$ & London \\
\hline \hline PublisherImprintName & $:$ & BioMed Central \\
\hline \hline
\end{tabular}

\title{
MRC under attack
}

\begin{tabular}{|l|l|l||}
\hline \multicolumn{2}{|c|}{ ArticleInfo } \\
\hline \hline ArticleID & $:$ & 4733 \\
\hline \hline ArticleDOI & $:$ & $10.1186 /$ gb-spotlight-20030326-03 \\
\hline \hline ArticleCitationID & $:$ & spotlight-20030326-03 \\
\hline \hline ArticleSequenceNumber & $:$ & 85 \\
\hline \hline ArticleCategory & $:$ & Research news \\
\hline ArticleFirstPage & $:$ & 1 \\
\hline \hline ArticleLastPage & $:$ & 3 \\
\hline \hline & & RegistrationDate : 2003-3-26 \\
\hline ArticleHistory & $:$ & OnlineDate \\
\hline \hline ArticleCopyright & $:$ & BioMed Central Ltd2003-26 \\
\hline \hline ArticleGrants & $:$ & \\
\hline \hline ArticleContext & $:$ & 130594411 \\
\hline \hline
\end{tabular}




\section{Pat Hagan}

Email: pat.hagan@btconnect.com

A committee of MPs has launched a scathing attack on the Medical Research Council (MRC), the largest public funder of medical research in the UK, accusing it of poor financial management and misguided strategies.

The damming verdict, by the House of Commons Science and Technology Select Committee, came in a report published March 25.

The report, The Work of the Medical Research Council, strongly criticizes the MRC for poor planning and focusing on expensive, long-term projects that are politically-driven and have diverted money away from "top quality grant proposals".

According to the MPs, the MRC has harmed its own reputation, caused "greater resentment" among researchers and discriminated against young scientists keen to get their work properly funded.

The unprecedented attack is the result of a detailed probe into the workings of the MRC. Last September, the committee announced it would be scrutinizing MRC activities as part of a rolling programme of investigating all science research councils.

At the time, it said it had two major areas of concern - the UK stem cell bank and the UK Biobank, two of the biggest projects in which the MRC is involved.

Biobank, a $£ 45$ million initiative to collect DNA samples from half-a-million volunteers, came in for stinging criticism in the final report. "It is not clear to us that Biobank was peer-reviewed and funded on the same basis as any other grant proposals," the report said. "Our impression is that a scientific case for Biobank has been put together by the funders to support a politically driven project."

MPs also railed against the MRC's attempts at consultation on the Biobank project, accusing the council of using the process to sanction the whole initiative rather than challenge it. "It is our impression that the MRC's consultation for Biobank has been a bolt-on activity to secure widespread support... rather than a genuine attempt to build a consensus on the project's aims and methods."

Perhaps the most disturbing accusation is that some of the best medical scientists in the UK have been starved of cash because of the MRC's preference for large-scale projects.

Labour MP Ian Gibson, who chairs the committee, told The Times newspaper: "This report emanated from a series of complaints from several scientists at major elite universities who had found their grants were not being awarded.

"Clearly, money is being diverted into other major projects at the expense of ongoing major research."

Save British Science director Peter Cotgreave told us the organization had voiced its concerns to the committee of MPs. "We said in our evidence that we were very worried about the drift towards bigger and bigger projects by the MRC. We have nothing against that, except where it happens at the expense of smaller projects involving individual researchers." 
Cotgreave claimed the MRC has all but abandoned one-off grants for scientists who may not be part of the research hierarchy and want to pursue small-scale projects. "They have completely done away with that, and I think it's mad."

The MRC presented a detailed rebuttal of the accusations on its website today. It rejected criticism of its planning process and said this can involve difficult decisions that are not always popular at the time. "For many years we were criticized for funding research into molecular biology because people questioned its relevance to health. The subsequent mapping of the human genome has demonstrated the importance of that investment."

It also insists the Biobank project was designed "to improve the health of the public and meet the research needs of the scientific community" and denies claims it has discriminated against young people.

Sir George Radda, chairman of the MRC, announced last year his intention to step down from the post in September. His successor has not yet been named.

\section{References}

1. Medical Research Council, [http://www.mrc.ac.uk/]

2. House of Commons Science and Technology committee, [http://www.parliament.uk/ parliamentary_committees/science_and_technology_committee.cfm]

3. The Work of the Medical Research Council, [http://www.parliament.the-stationery-office.co.uk/pa/ cm200203/cmselect/cmsctech/132/13202.htm]

4. UK Biobank, [http://www.mrc.ac.uk/index/public-interest/public-news/public-news_archive/publicnews_archive_1_2002/public-biobank_uk.htm]

5. Hagan P: Tracking genes and disease. The Scientist, January 21, 2002., [http://www.thescientist.com/news/20020121/03/]

6. Gavaghan H: Cut and thrust of parliamentary life. The Scientist, February 18, 2003., [http://www.thescientist.com/news/20030218/06/]

7. The Times, [http://www.timesonline.co.uk/]

8. Save British Science, [http://www.savebritishscience.org.uk/]

9. MRC response, [http://www.mrc.ac.uk/index/public-interest/public-press_office/publicpress_releases_2003/public-25_march_2003.htm] 